Article

\title{
Online Database for Retrieval Information about Prebiotics and Their Activity
}

\author{
Elena Guseva ${ }^{1, *}$, Boris Karetkin ${ }^{2}$, Diana Batyrgazieva ${ }^{1} @$, Natalia Menshutina ${ }^{1}$ \\ and Victor Panfilov ${ }^{2}$ \\ 1 Department of Cybernetics of Chemical Technological Processes, D. Mendeleev University of Chemical \\ Technology of Russia, Miusskaya Sq., 9, 125047 Moscow, Russia; Diana.b1994@mail.ru (D.B.); \\ chemcom@muctr.ru (N.M.) \\ 2 Department of Biotechnology, D. Mendeleev University of Chemical Technology of Russia, Miusskaya Sq., 9, \\ 125047 Moscow, Russia; karetkin@muctr.ru (B.K.); vip@muctr.ru (V.P.) \\ * Correspondence: eguseva@muctr.ru; Tel.: +7-(495)-495-0029
}

Received: 9 April 2020; Accepted: 7 May; Published: 11 May 2020

check for updates

\begin{abstract}
The number of studies aimed at proving the prebiotic properties of certain substances or compositions has been actively increasing, which has led to a large accumulation of scientific information that is fragmented and not systematized. Moreover, a number of criteria have been applied in these studies. The lack of an accessible and convenient information space to compare the obtained results seems to hold back not only scientific development, but also practical development in this field. A database called the «On-line Database of Researches on Activity of Prebiotics» (ODRAP) is presented in this article, which contains information about both prebiotics and some probiotics, that were used in these researches. Currently, ODRAP collects 25 bacteria genera or their combinations, 59 bacteria species, 140 prebiotic substances, 61 prebiotic production companies, 2 methods of fermentation, and 271 analyzed articles from 2001 till 2019. To facilitate access to the database, a special Web-interface was created, which allows any user who opens the Web-page to obtain information about the features and activities of prebiotics, as well as to sort the data by species and genus of bacteria applied in tests, the chemical nature or source of prebiotics, and other parameters. The convenience of the Web-interface is that it allows access to the database, regardless of the user platform and from anywhere, via the Internet.
\end{abstract}

Keywords: online database; web-interface; prebiotics activity; probiotics; synbiotic factors

\section{Introduction}

The human body is a complex system consisting of about $10^{14}$ microbial cells interacting with the host [1,2]. The essential role of the gut microbiota for health has generated tremendous interest in modulating its composition and metabolic function. One of these strategies is using prebiotics, which typically refers to selectively fermented non-digestible food ingredients or substances that specifically support the growth and/or activity of health-promoting bacteria (probiotics) that colonize the gastrointestinal tract [3-5]. As noted by Hill C. et al. [6] probiotics are «live micro-organisms which when administered in adequate amounts confer a health benefit on the host. Prebiotics were defined as a non-digestible food ingredient that beneficially affects the host by selectively stimulating the growth and/or activity of one or a limited number of bacteria in the colon, and thus improves host health» [7]. There are number of information systems and databases which have made it possible to collect various microbiological data, among which online databases should be highlighted [8-12].

The main purpose of Online Databases and Internet resources for science is to group data together and provide URLs and hyperlinks, such that any researcher, teacher, or student can access 
them with minimal effort, time, and cost $[13,14]$. However, there are not a lot of databases or information systems in the fields of prebiotics and related to probiotics. A probiotics database named PROBIO was developed to facilitate these efforts and to address the need for information on the known probiotics, providing comprehensive information about the functions of marketed probiotics, clinical/field trials, and research probiotics for use or being studied for use in humans, animals, and plants [15]. This probiotic databases are typically focused on clinical research in vitro or animal studies. The probiotic database PBDB [16] includes information about different probiotics sourced from fermented foods. Information about other Probiotics databases has been presented by the Probiotic Professionals site, where the most researched probiotic strains in the world are collected [17]. The strains have been chosen due to both the quantity and quality of the research behind them, but mainly by the quality. Some Web-sites of organizations specialize in the investigation of probiotics and prebiotics, such as that of the Global Prebiotic Association [18], where links on this theme have been collected.

When considering prebiotics, it is necessary to pay great attention to their activity, which is an important task for estimating the perspectives of using such substances as prebiotics. There are different methods to evaluate prebiotic activity. The most commonly used technique for prebiotic activity evaluation in vitro is based on the fermentation of mixed faecal cultures of healthy donors, which was first applied by Japanese researchers in the 1980s [19]. Simple batch fermentations are carried out and the $\mathrm{pH}$ is kept under control or not. Non-cultural methods of bacteria enumeration, such as fluorescence in situ hybridization (FISH) and polymerase chain reaction (PCR), have greatly enhanced the accuracy of prebiotic activity assessment. The range of analyzed prebiotics has been greatly expanded recently: exopolysaccharide from Cordyceps sinensis Cs-HK1 [20], xylooligosaccharides produced by Bacillus subtilis 3610 [21], extracts of brown seaweed [22], and so on. Basing on the data obtained from the fermentation of fecal cultures, Palframan, Gibson, and Rastall [23] suggested calculation of a prebiotic index (PI), which was determined as the difference between the number of probiotics and non-probiotics at the end of the fermentation. Vulevic, Rastall, and Gibson [24] replaced the number of bacteria by the specific growth rate, which demonstrated the relationship to the kinetic patterns of micro-organism growth; however, the mechanism of their interaction in a mixed culture remains hidden. The prebiotic index has been used, for example, to study wheat food grade curdlan (1->3)-beta-D-glucan) from Alcaligenes faecalis [25] or oligo-glucomannan from Amorphophallus konjac [26]. The "useful" bacteria (typically, Bifidobacterium and Lactobacillus genera) from faeces are took into account in the mentioned techniques, not pure cultures of probiotics. The "harmful" Clostridium and Bacteroides are commonly recognized as antagonists, means that their specific growth rates are included in the equation with "minuses". This approach is related to the prebiotic concept. Moreover, as Palframan et al. pointed [23], PI allows to compare the results of different researches on prebiotics.

Methods for prebiotic activity evaluation which apply pure cultures are not utterly informative, as it is not possible to take into account the interaction of bacteria. However, Huebner et al. [27] proposed a quantitative measure of prebiotic activity, the prebiotic activity score. Its dimension is based on the comparison of specific growth rates. The prebiotic activity score is less common, although it has been used in a number of studies [28-31]. The well known probiotic bacteria such as Bifidobacterium lactis subsp. animalis Bb-12 or Lactobacillus rhamnosus GG, are commonly used. So called enteric mixture (a lot of Escherichia coli strains) is supposed as antagonists. One of the most common models of the intestine is a three-stage continuous culture, as proposed by Macfarlane et al. [32]. Using this method, the prebiotic effect, which has also been associated with an increase in the number of probiotics and production of SCFA, has been evaluated, for example, for mixture of galactooligosaccharides, lactose, glucose and galactose (B-GOS) [33] and fructans with differing in degree of polymerization [34]. 'A mixture of synergistically acting probiotics and prebiotics' has been defined as synbiotics [7]. Synbiotics incorporate the properties of probiotic and prebiotic ingredients and provide a greater effect than that of the probiotics or prebiotics separately. One of approaches to 
assessing such synergism in vitro is the co-culturing of probiotic bacteria with selected pathogens in prebiotic contained media [35-38].

The criteria obtained from a quantitative model of co-culture has been suggested for the comparison of symbiotic activity against pathogens in different conditions [39]. Analysis of existing databases on prebiotics and probiotics has shown that there are no such databases containing information about prebiotic activities and the methods for their evaluation. In this paper, a developed online database (ODRAP) is presented, which includes unique content concerning different probiotics and prebiotics, along with their activities.

\section{Materials and Methods}

The database was implemented using MS Office Access 2013 (https://products.office.com/ ru-ru/access/). The Web-interface was written using the programming language Python (https: / / www.python.org/) and technology with the Django framework (https://www.djangoproject.com/). For the client part, HTML (http:/ / htmlbook.ru/html), CSS (https:/ / drafts.csswg.org/), Javascript, and js, as well as the Vue.js library, were used. The ODRAP database is freely available at https: / /rs-pharmcenter.com/rnf2019/db2/index.html?page=1.

\section{Results}

\subsection{The ODRAP Database}

Conceptual and logical models of the database were first developed. The in vitro studies were our main focus. Database tables were attached to each object in the conceptual model, containing the corresponding object attributes, and relationships between tables in the logical model were established using primary keys. This is reflected in the infological diagram of the database (Figure 1) which reflects the relationships between these data groups were defined. One medium can be applied for the fermentation of different probiotics, a given probiotic can be used with different prebiotics, one cultivation method can be applied to different prebiotics, one set of metabolites can be suitable for different prebiotics, and so on [40,41].

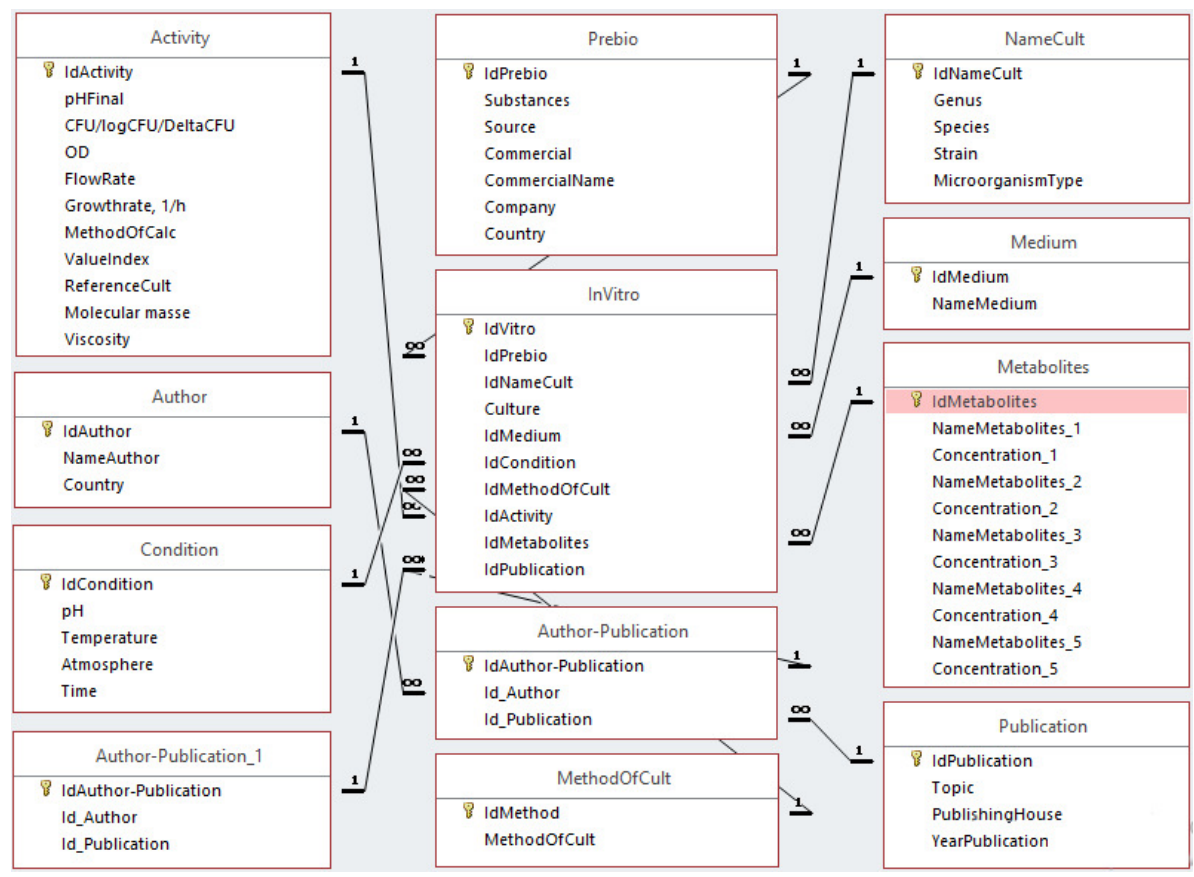

Figure 1. Infological diagram of the database, which reflects the relation between all data groups (1 means one parameter from one group, $\infty$ means many different parameters from another group, for example, one medium can be applied for the fermentation for different prebiotic tests). 
The database includes 12 main and auxiliary tables which describe the parameters of the main elements. The table «Activity» (Figure 2) contains information about the main physiological features of the micro-organisms [42-44]. Such parameters as final $\mathrm{pH}$ of fermentation, viable micro-organisms count, optical density, and information about the flowrate and growth rate, as well as methods for prebiotic activity definition: prebiotic activity score (PAS), measure of the prebiotic effect (MPE), prebiotic index (PI), synbiotic index (SI), and synbiotic factor (SF), are highlighted [45].

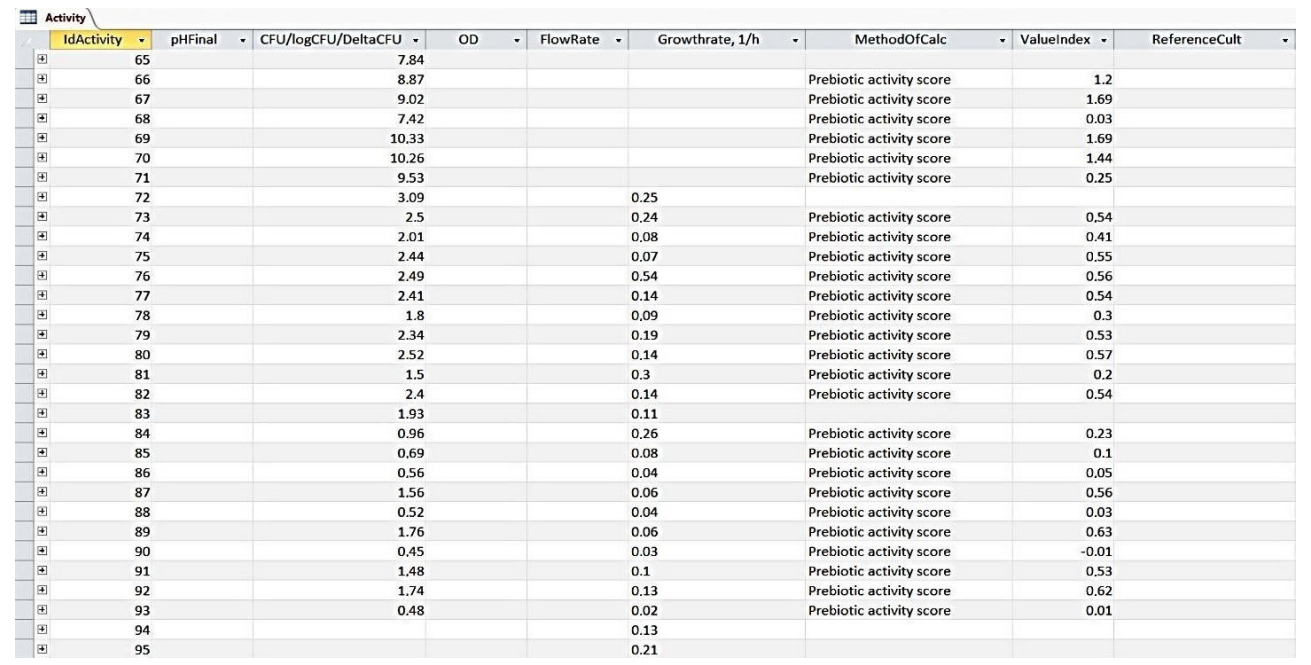

Figure 2. Table «Activity» containing information about the main physiological parameters of the micro-organisms growth on prebiotics (for example, final $\mathrm{pH}$ of fermentation, viable micro-organisms count, different methods for prebiotic activity definition and etc.).

The cultivation conditions are contained in the table «Condition», which are $\mathrm{pH}$, temperature, atmosphere, and time [46,47]. Figure 3 «Prebio» is key table stored data on prebiotic substances, source of origin, and information about manufacturer. Data on microbiological cultures and their features are concentrated in the table «NameCult» (Figure 4). In this part of the database, various types of micro-organisms, their genus, species, and strains are considered. For the methods using faecal cultures Bifidobacteria and Lactobacillus were indicated as probiotics. Although assumption is rather conditional it was introduced considering that the increasing of such bacteria count is associated with benefits for the human. Moreover, it was decided to simplify the structure of database. The following micro-organisms were taken into account for the methods based on the pure cultures fermentation: Bifidobacterium animalis Bb-12, Lactobacillus rhamnosus GG, Bifidobacterium bifidum, Lactobacillus plantarum, and so on. The test cultures for PAS or SF evaluation were recognized as probiotics by authors. While filling the tables, popular commercial probiotic micro-organisms were taken into account, as well as variants of mixed types developed by various researchers [48].

The table «Author-Publication» allows connection between the tables «Author» and «Publication». These tables contain information about manuscripts published mainly over the past 20 years, including the name of author, title, topic and year of publication, title of journal, for example, Journal of functional foods, and etc. The table «In vitro», being the key table, joins the main information from the tables «Prebio», «NameCult», «Medium», «Condition», «Activity», «Metabolites», and «Author-Publication». Currently, ODRAP collects 25 bacteria genera or their combinations, 59 bacteria species, 140 prebiotic substances, 61 prebiotic production companies, 2 methods of fermentation, and 271 analyzed articles. Thus, the created database allows users to sort and systematize the necessary data on probiotics, both known and created by experts, and about various substances that can serve as prebiotics. The advantages and key point of the ODRAP database is the information concerning prebiotic activities and various methods of their assessment. This database will allow for analysis and comparison of a lot of data to improve future research. 


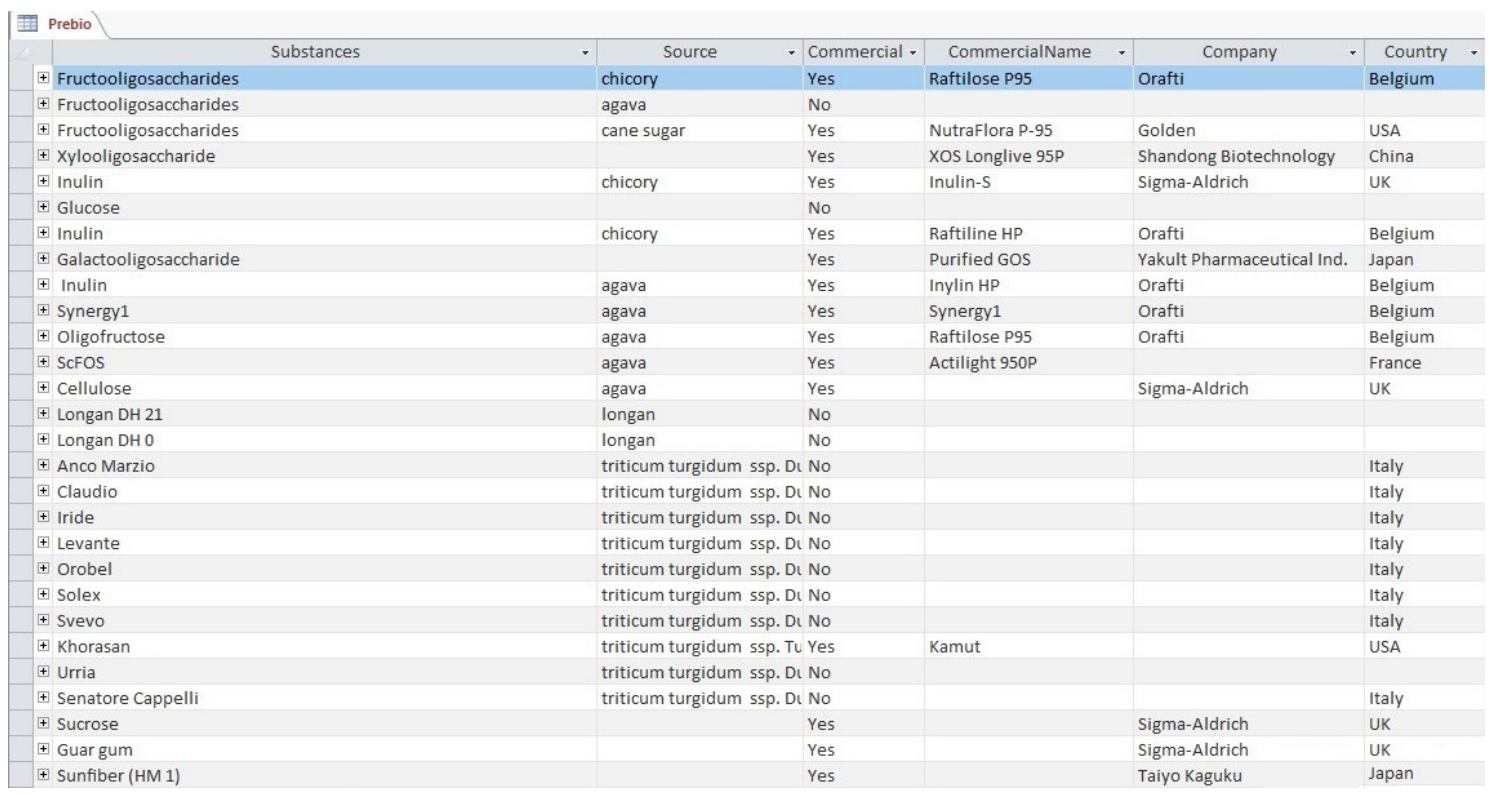

Figure 3. Table «Prebio» containing the key data on prebiotics-substance, source of origin, and information about manufacturer. The cell "Commercial" was filled by value "no" if new, non traditional sources of prebiotics was applied in the researches. This should help the users to recognize the features of some plants.

\begin{tabular}{|c|c|c|c|c|c|}
\hline & IdNameCult . & Genus & Species & Strain & Microorgani - \\
\hline 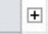 & + & 1 Bifidobacterium & bifidum & $\mathrm{NCl}$ & Probiotic \\
\hline+ & + & 2 Escherichia & coli & & No probiotic \\
\hline$\oplus$ & + & 3 Bifidobacterium & adolescentis & ATCC 15706 & Probiotic \\
\hline$\oplus$ & + & 4 Bifidobacterium + Lactobacillus & & faecal & Probiotic \\
\hline$\oplus$ & + & 5 Bacteroides + Clostridium & & faecal & No probiotic \\
\hline 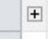 & + & 6 Bifidobacterium & & faecal & Probiotic \\
\hline$\Phi$ & + & 7 Bifidobacterium & longum & 15708 & Probiotic \\
\hline$\oplus$ & + & 8 Bifidobacterium & adolescentis & 15706 & Probiotic \\
\hline$\oplus$ & + & 9 Bifidobacterium & infantis & 17930 & Probiotic \\
\hline 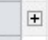 & 1 & 0 Bifidobacterium & breve & 15698 & Probiotic \\
\hline$\oplus$ & 1. & 11 Lactobacillus & acidophilus & 33200 & Probiotic \\
\hline 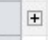 & 1. & 2 Lactobacillus & acidophilus & NCFM & Probiotic \\
\hline$\oplus$ & 1 & 13 Lactobacillus & plantarum & 12006 & Probiotic \\
\hline$\oplus$ & 1 & 14 Lactobacillus & plantarum & 4008 & Probiotic \\
\hline+ & 1. & 15 Lactobacillus & paracasei & 1195 & Probiotic \\
\hline+ & 1 & 16 Lactobacillus & plantarum & L12 & Probiotic \\
\hline$\oplus$ & 1 & 17 Bifidobacterium & pseudocatenulatur & B7003 & Probiotic \\
\hline$\oplus$ & 1 & 18 Lactobacillus & acidophilus & La5 & Probiotic \\
\hline 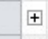 & 1 & 9 Bifidobacterium & lactis & $\mathrm{Bb} 12$ & Probiotic \\
\hline$\oplus$ & 2 & 20 Escherichia & coli & ATCC 25922 & No probiotic \\
\hline$\oplus$ & 2 & 1 Bifidobacterium & & Bif 164 & Probiotic \\
\hline$\oplus$ & 2. & 22 Lactobacillus & & Lab 158 & Probiotic \\
\hline$\oplus$ & 2 & 3 Escherichia & coli & ATCC 25645 & No probiotic \\
\hline$\oplus$ & 2 & 24 Klebsiella & pneumoniae & GC 23a & Pathogen \\
\hline$\oplus$ & 2 & 25 Enterobacter & cloacae & GC & No probiotic \\
\hline$\dagger$ & 2 & 26 Eubacterium & rectale & Erec 482 & No probiotic \\
\hline$\oplus$ & 2 & 27 Bacteroides & & Bac 303 & No probiotic \\
\hline 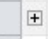 & 2 & 28 Clostridium & histolyticum & Chis 150 & Pathogen \\
\hline 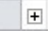 & 2 & 9 Escherichia & coli & Ec 1531 & No probiotic \\
\hline
\end{tabular}

Figure 4. Table «NameCult» containing the information about various types of micro-organisms.

\subsection{The Web-Interface}

The specially written Web-interface allows a user who opens a Web-page to become familiarized with information on prebiotics and their activities, sort by type and genus of probiotic, and other parameters [49]. The Web-application connecting to the database server consists of client and server 
parts [50]. The client part implements the user interface, while the server part receives and processes queries from the client, performs calculations, forms a Web-page, and sends it to the client according to the HTTP protocol. The programming language Python and the Django framework were used to create the server part [51]. HTML, CSS, JavaScript, and the library Vue.js were used for the client part $[52,53]$. The client application allows a user to use the following search parameters:

- bacteria genus;

- bacteria species;

- prebiotic substances;

- company producer of prebiotic;

- method of fermentation; and

- $\quad$ author of article.

Figure 5 shows the main page of the Web-application. Access is provided through a browser (e.g., Internet Explorer, Edge, Safari, Firefox, or Chrome). In the browser, a Web-page can be opened by entering the following URL: https:/ /rs-pharmcenter.com/rnf2019/db2/index.html?page=1. On the left side of the main page of the Web-application, the search options can be found. These parameters can be selected both individually or together, depending on the task. The Figure 6 is example of search on prebiotic substances. FOS (fructo-oligosaccharides) was selected as prebiotic substance. In ODRAP database 64 records with it were found. On the Figure 7 the example of search on author of article is shown. If the name Gibson G.R. will be selected 212 records could be found.

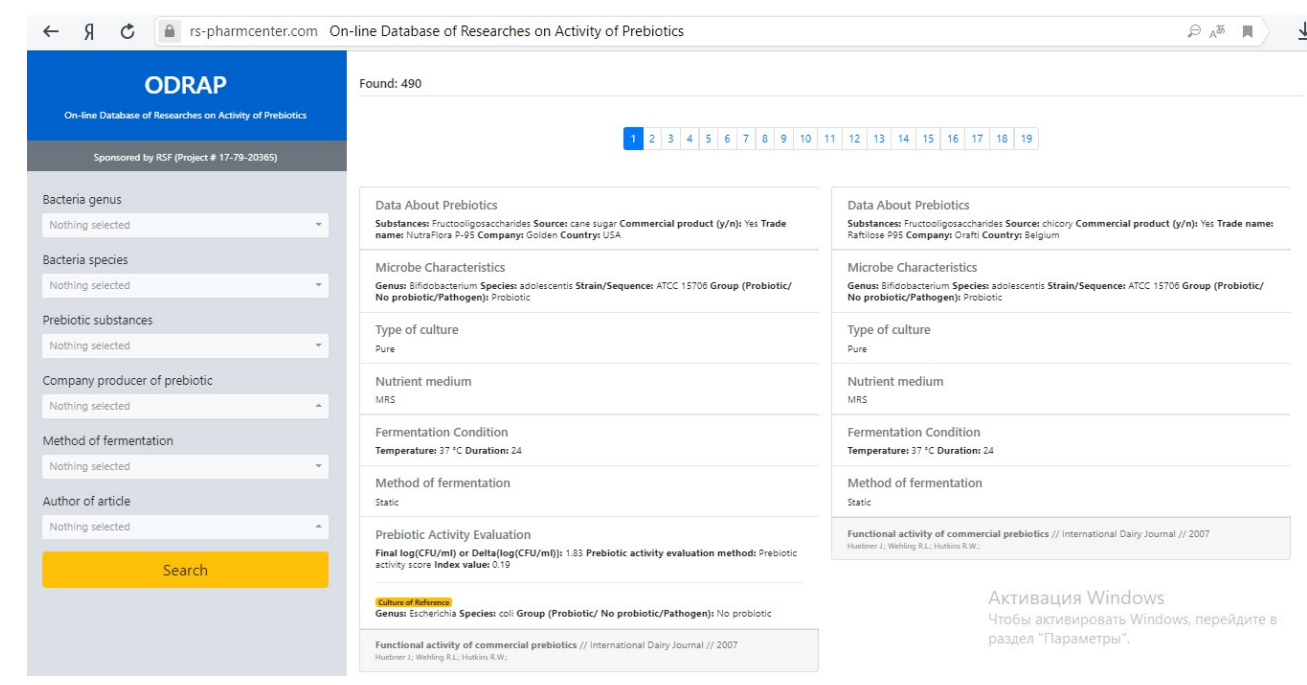

Figure 5. The main page of the Web-application of ODRAP database.

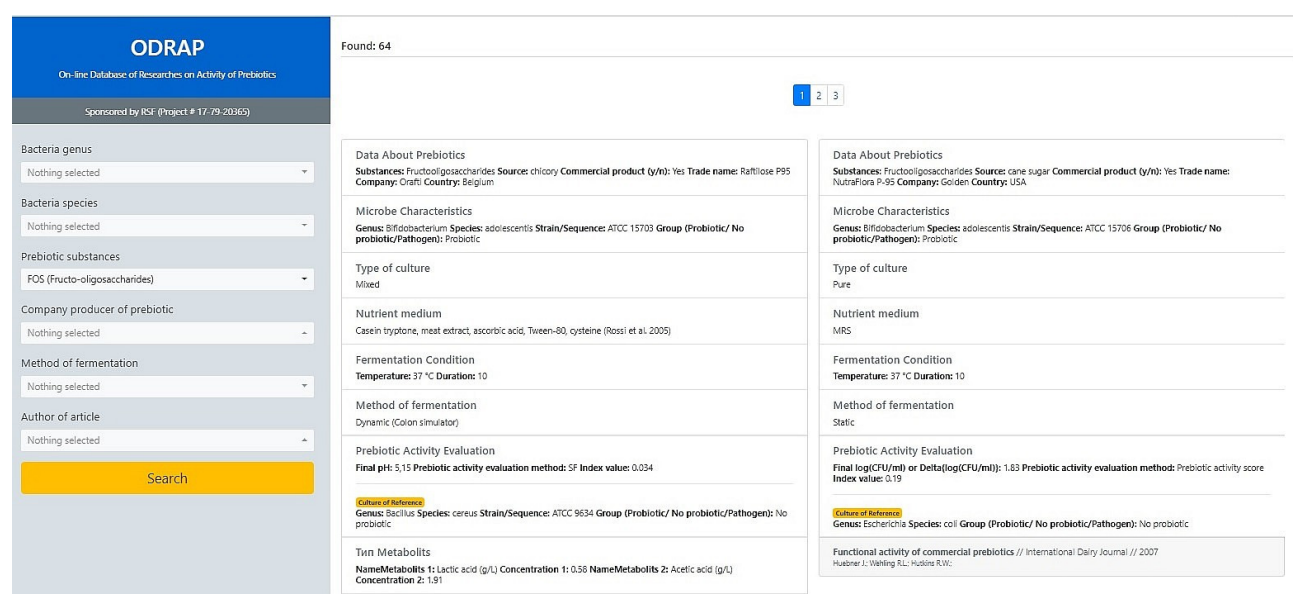

Figure 6. Example of search: FOS (fructo-oligosaccharides) was selected as prebiotic substance, 64 records with FOS were found. 

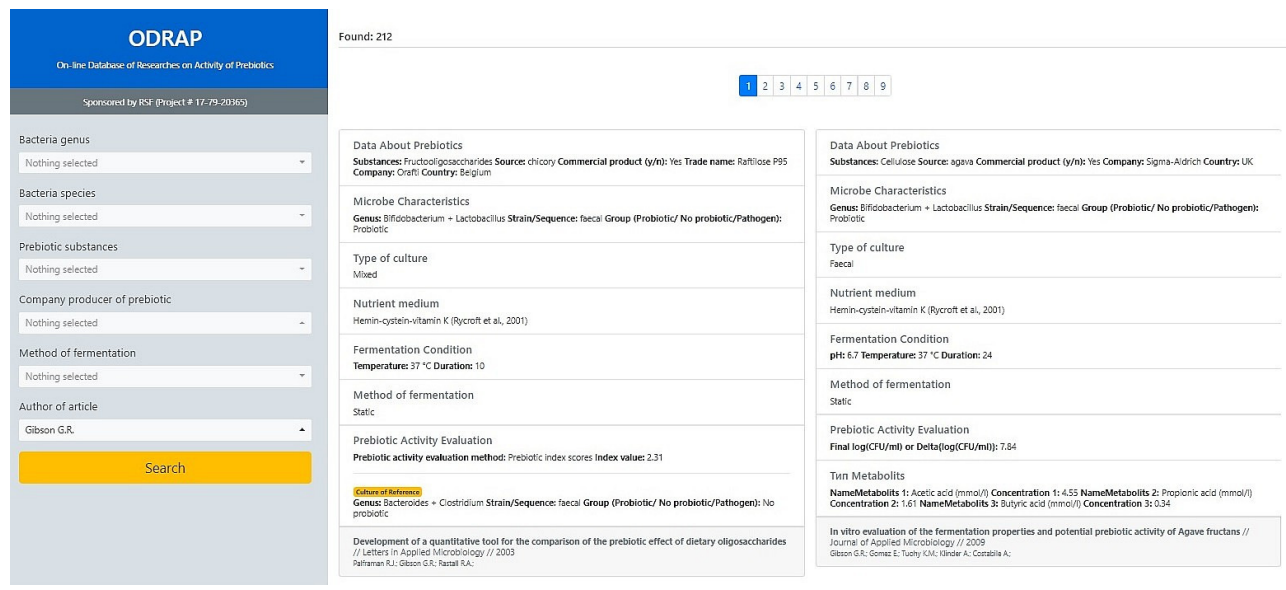

Figure 7. Example of search: the name of author of article is Gibson G.R., 212 records could be found.

Besides, it could be possible to make a joint search (Figure 8). The search query was on 3 search parameters:

- bacteria genus: Bifidobacterium+Lactobacillus+Eubacteria;

- $\quad$ author of article: Chaiongharn A.;

- method of fermentation: Static.

As a result, six prebiotics were found.

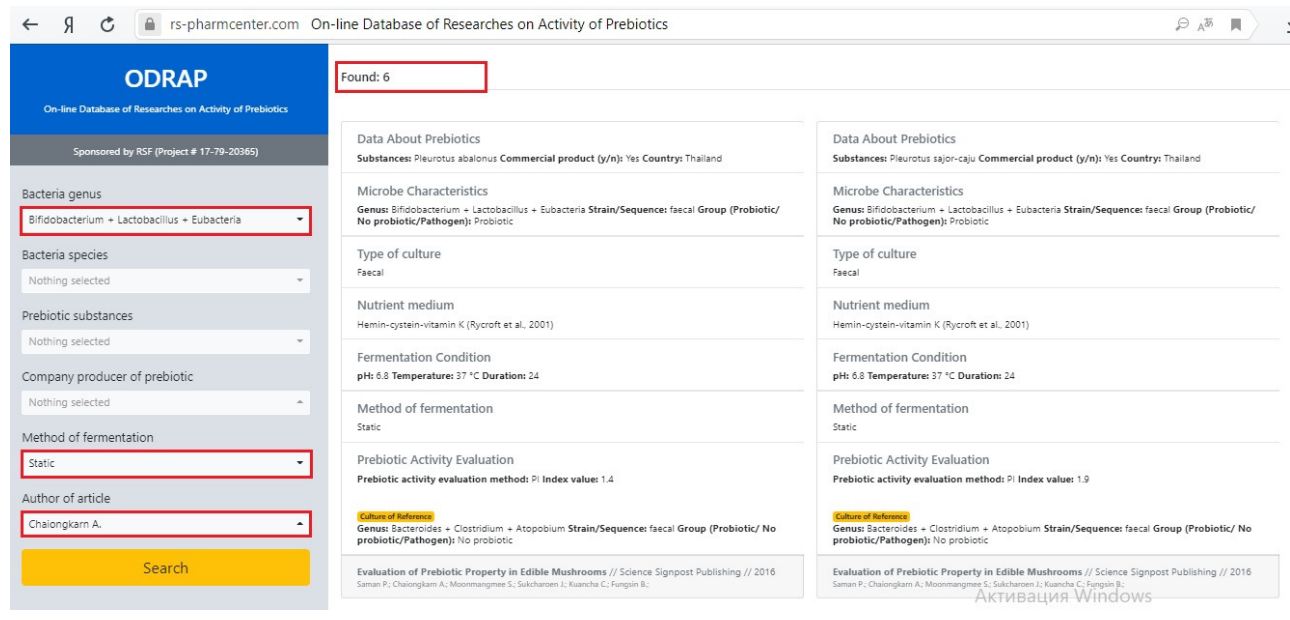

Figure 8. Result of joint search: 3 search parameters were: bacteria genus-“Bifidobacterium+Lactobacillus+ Eubacteria", author of article- "Chaiongharn A.", method of fermentation—“Static". As a result, six prebiotics were found.

Figure 9 illustrates the criteria SF obtained from the quantitative model of co-culture suggested for comparison of symbiotic activity against pathogens in different conditions [35].

Access to viewing information in the database is opened to any user by entering the following URL: https://rs-pharmcenter.com/rnf2019/db2/index.html?page=1. Entering, changing and deleting data is possible only through the database server. The database server is managed by the administrator, who has full rights to create, modify and delete data, and can provide users with access rights to manage data through an account. Currently, only a limited number of users have permission to the server. In the future, manage to the database server can be expanded for users through a registration form with the ability to enter information. This will protect against unauthorized copying, modification or exception of database records and tables.

Thus, by means of the Web-application of ODRAP database, a user can obatin information on the specific concerning the fields of prebiotics and their activity used with a number of probiotics. 
It should be mentioned that the main advantage of the Web-application is the fact that it does not depend on a particular operating system, as Web-applications are cross-platform services.

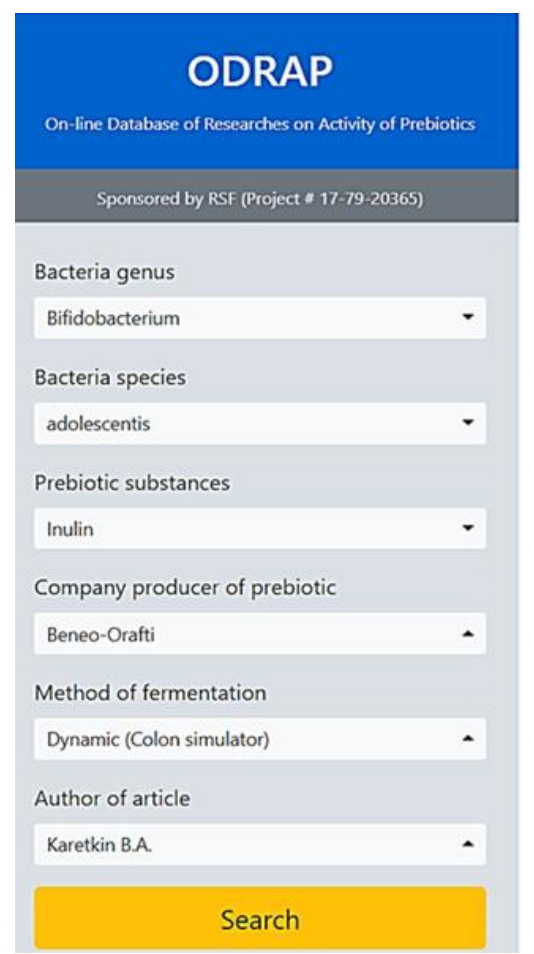

\begin{tabular}{|l|}
\hline Found: 1 \\
\hline $\begin{array}{l}\text { Data About Prebiotics } \\
\text { Substances: Inulin Commercial product (y/n): yes Trade name: Orafti GR Company: } \\
\text { Beneo-Orafti Country: Belgium }\end{array}$ \\
\hline $\begin{array}{l}\text { Microbe Characteristics } \\
\text { Genus: Bifidobacterium Species: adolescentis Strain/Sequence: ATCC } 15703 \text { Group } \\
\text { (Probiotic/ No probiotic/Pathogen): Probiotic }\end{array}$ \\
\hline $\begin{array}{l}\text { Type of culture } \\
\text { Mixed }\end{array}$ \\
\hline $\begin{array}{l}\text { Nutrient medium } \\
\text { Casein tryptone, meat extract, ascorbic acid, Tween-80, cysteine (Rossi et al. 2005) }\end{array}$ \\
\hline $\begin{array}{l}\text { Fermentation Condition } \\
\text { Temperature: } 37{ }^{\circ} \mathrm{C} \text { Duration: } 10\end{array}$ \\
\hline $\begin{array}{l}\text { Method of fermentation } \\
\text { Dynamic (Colon simulator) }\end{array}$ \\
\hline $\begin{array}{l}\text { Prebiotic Activity Evaluation } \\
\text { Final pH: } 5.21 \text { Prebiotic activity evaluation method: SF Index value: } 0.029\end{array}$ \\
\hline $\begin{array}{l}\text { Culture of Reference } \\
\text { Genus: Bacillus Species: cereus Strain/Sequence: ATCC } 9634 \text { Group (Probiotic/ No } \\
\text { probiotic/Pathogen): No probiotic }\end{array}$ \\
\hline
\end{tabular}

Figure 9. Example of search: synbiotic factor SF obtained from the quantitative model of co-culture suggested for comparison of symbiotic activity against pathogens in different conditions [35].

\section{Conclusions}

In this paper, we present the ODRAP database, which is based on the information of articles by various researchers and implemented using MS Office Access 2013 [54,55]. The implemented database is specific and it was assigned for the scientists working in microbiology and biotechnology. This database allows to search for necessary information concerning prebiotics and their activity by definite parameters. The advantage of using MS Office Access 2013 is its integration into desktop PCs, ability to export and convert data, and a wide range generation of forms, reports, and queries which can be used to sort data and enter it in a convenient manner [56]. This data structure is unique, as it contains information about the assessment of prebiotic activities in vitro and the different methods used to define them. A Web-application, with a user-friendly Web-interface, was implemented for convenient user access to the database, which provides the ability to search for information in a specific direction and priorities in the fields prebiotics and their activity $[57,58]$. A Web-interface passed the test period and was approved by our colleagues. It is planned to update this version of ODRAP database after receive sufficient statistics on navigation adjustments and recommendations. The implemented database will be updated depending on the accumulation of data on research in this field. The ability to upload new information in the database by users or researchers has great prospects and allows to increase speed of data update. However, the significant redesign of the interface and the development of data verification system are required. Currently, ODRAP collects information 25 bacteria genera or their combinations, 59 bacteria species, 140 prebiotic substances, 61 prebiotic production companies, 2 methods of fermentation, and 271 analyzed articles from 2001 till 2019. Criteria such as PI, PAS or SF can be compared using ODRAP database for the same prebiotic substances, but for different probiotic bacteria, or for substances of a similar nature obtained from different sources. In addition, such important information for the scientist working in microbiology as the production of metabolites (organic acids), which largely determine the suppression of the growth 
of pathogens, can be taken into account. In present version of the DB in vitro studies of prebiotic activity are included, as they are more numerous. In the future the DB can be expanded with data obtained in animals and humans studies in vivo.

Author Contributions: Conceptualization, E.G.; Formal analysis, B.K. and N.M.; Funding acquisition, B.K.; Investigation, B.K.; Methodology, B.K. and D.B.; Project administration, B.K.; Software, D.B.; Supervision, E.G.; Validation, N.M. and V.P.; Visualization, D.B.; Writing-original draft, E.G., B.K., and D.B.; Writing-review \& editing, E.G., B.K., and D.B All authors have read and agreed to the published version of the manuscript.

Acknowledgments: Present study was supported by Russian Science Foundation (Project № 17-79-20365).

Conflicts of Interest: The authors declare no conflict of interest. The funders had no role in the design of the study; in the collection, analyses, or interpretation of data; in the writing of the manuscript, or in the decision to publish the results.

\section{Abbreviations}

The following abbreviations are used in this manuscript:

$\begin{array}{ll}\text { PAS } & \text { Prebiotic activity score } \\ \text { MPE } & \text { Measure of the prebiotic effect } \\ \text { PI } & \text { Prebiotic Index } \\ \text { SI } & \text { Synbiotic index } \\ \text { SF } & \text { Synbiotic factor }\end{array}$

\section{References}

1. Enam, F.; Mansell, T.J. Prebiotics: Tools to manipulate the gut microbiome and metabolome. J. Ind. Microbiol. Biotechnol. 2019, 46, 1445-1459. [CrossRef] [PubMed]

2. Tuohy, K.M.; Probert, H.M.; Smejkal, C.W.; Gibson, G.R. Using probiotics and prebiotics to improve gut health. Drug Discov. Today 2003, 8, 692-700. [CrossRef]

3. Bindels, L.B.; Delzenne, N.M.; Cani, P.D.; Walter, J. Towards a more comprehensive concept for prebiotics. Nat. Rev. Gastroenterol. Hepatol. 2015, 12, 303. [CrossRef] [PubMed]

4. Chaluvadi, S.; Hotchkiss, A.T.; Yam, K.L. Gut Microbiota. In Probiotics, Prebiotics, and Synbiotics; Elsevier: Amsterdam, The Netherlands, 2016; pp. 515-523. [CrossRef]

5. Shokrvash, B.; Homayouni, A.; Payahoo, L.; Biglu, M.H.; Mehrabany, E.V.; Jafarabadi, M.A. Probiotics and Health. In Probiotics, Prebiotics, and Synbiotics; Elsevier: Amsterdam, The Netherlands, 2016; pp. 691-698. [CrossRef]

6. Hill, C.; Guarner, F.; Reid, G.; Gibson, G.R.; Merenstein, D.J.; Pot, B.; Morelli, L.; Canani, R.B.; Flint, H.J.; Salminen, S.; et al. The International Scientific Association for Probiotics and Prebiotics consensus statement on the scope and appropriate use of the term probiotic. Nat. Rev. Gastroenterol. Hepatol. 2014, 11, 506-514. [CrossRef] [PubMed]

7. Gibson, G.R.; Roberfroid, M.B. Dietary modulation of the human colonic microbiota: Introducing the concept of prebiotics. J. Nutr. 1995, 125, 1401-1412. [CrossRef]

8. Bello, M.G.D.; Knight, R.; Gilbert, J.A.; Blaser, M.J. Preserving microbial diversity. Science 2018, 362, 33-34. [CrossRef]

9. Diminic, J.; Zucko, J.; Ruzic, I.T.; Gacesa, R.; Hranueli, D.; Long, P.F.; Cullum, J.; Starcevic, A. Databases of the thiotemplate modular systems (CSDB) and their in silico recombinants (r-CSDB). J. Ind. Microbiol. Biotechnol. 2013, 40, 653-659. [CrossRef]

10. Kosina, S.M.; Greiner, A.M.; Lau, R.K.; Jenkins, S.; Baran, R.; Bowen, B.P.; Northen, T.R. Web of microbes (WoM): A curated microbial exometabolomics database for linking chemistry and microbes. BMC Microbiol. 2018, 18, 1-10. [CrossRef]

11. Sun, Q.; Liu, L.; Wu, L.; Li, W.; Liu, Q.; Zhang, J.; Liu, D.; Ma, J. Web resources for microbial data. Genom. Proteom. Bioinform. 2015, 13, 69-72. [CrossRef]

12. Microbesonline. Technical Report. Available online: http://meta.microbesonline.org/ (accessed on 8 April 2020). 
13. Venkataramana, P. Online Databases and Other Internet Resources for Earth Science; Chandos Information Professional Series; Elsevier Science: Amsterdam, The Netherlands, 2007.

14. What Is the Key Best Practice for Collaborating with a Computational Biologist? Cell Syst. 2016, 3, 7-11. [CrossRef]

15. Tao, L.; Wang, B.; Zhong, Y.; Pow, S.H.; Zeng, X.; Qin, C.; Zhang, P.; Chen, S.; He, W.; Tan, Y.; et al. Database and bioinformatics studies of probiotics. J. Agric. Food Chem. 2017, 65, 7599-7606. [CrossRef]

16. Zhao, W.; Liu, Y.; Latta, M.; Ma, W.; Wu, Z.; Chen, P. Probiotics database: A potential source of fermented foods. Int. J. Food Prop. 2019, 22, 198-217. [CrossRef]

17. Probiotics Database. Technical Report. Available online: http://www.optibacprobiotics.com/uk/professionals/ probiotics-database (accessed on 8 April 2020).

18. Prebioticassociation. Technical report. Available online: http://prebioticassociation.org/ (accessed on 8 April 2020).

19. Wang, X.; Gibson, G. Effects of the in vitro fermentation of oligofructose and inulin by bacteria growing in the human large intestine. J. Appl. Bacteriol. 1993, 75, 373-380. [CrossRef]

20. Mao, Y.H.; Song, A.X.; Li, L.Q.; Siu, K.C.; Yao, Z.P.; Wu, J.Y. Effects of exopolysaccharide fractions with different molecular weights and compositions on fecal microflora during in vitro fermentation. Int. J. Biol. Macromol. 2020, 144, 76-84. [CrossRef]

21. Amorim, C.; Silvério, S.C.; Cardoso, B.B.; Alves, J.I.; Pereira, M.A.; Rodrigues, L.R. In vitro assessment of prebiotic properties of xylooligosaccharides produced by Bacillus subtilis 3610. Carbohydr. Polym. 2020, 229, 115460. [CrossRef]

22. Charoensiddhi, S.; Conlon, M.A.; Vuaran, M.S.; Franco, C.M.; Zhang, W. Impact of extraction processes on prebiotic potential of the brown seaweed Ecklonia radiata by in vitro human gut bacteria fermentation. J. Funct. Foods 2016, 24, 221-230. [CrossRef]

23. Palframan, R.; Gibson, G.; Rastall, R. Development of a quantitative tool for the comparison of the prebiotic effect of dietary oligosaccharides. Lett. Appl. Microbiol. 2003, 37, 281-284. [CrossRef]

24. Vulevic, J.; Rastall, R.A.; Gibson, G.R. Developing a quantitative approach for determining the in vitro prebiotic potential of dietary oligosaccharides. FEMS Microbiol. Lett. 2004, 236, 153-159. [CrossRef]

25. Shi, Y.; Liu, J.; Yan, Q.; You, X.; Yang, S.; Jiang, Z. In vitro digestibility and prebiotic potential of curdlan $(1 \rightarrow 3)$ - $\beta$-d-glucan oligosaccharides in Lactobacillus species. Carbohydr. Polym. 2018, 188, 17-26. [CrossRef]

26. Ariestanti, C.A.; Seechamnanturakit, V.; Harmayani, E.; Wichienchot, S. Optimization on production of konjac oligo-glucomannan and their effect on the gut microbiota. Food Sci. Nutr. 2019, 7, 788-796. [CrossRef]

27. Huebner, J.; Wehling, R.; Hutkins, R.W. Functional activity of commercial prebiotics. Int. Dairy J. 2007, 17, 770-775. [CrossRef]

28. De Melo, F.H.C.; Menezes, F.N.D.D.; de Sousa, J.M.B.; dos Santos Lima, M.; da Silva Campelo Borges, G.; de Souza, E.L.; Magnani, M. Prebiotic activity of monofloral honeys produced by stingless bees in the semi-arid region of Brazilian Northeastern toward Lactobacillus acidophilus LA-05 and Bifidobacterium lactis BB-12. Food Res. Int. 2020, 128, 108809. [CrossRef]

29. Praveen, M.A.; Parvathy, K.K.; Jayabalan, R.; Balasubramanian, P. Dietary fiber from Indian edible seaweeds and its in-vitro prebiotic effect on the gut microbiota. Food Hydrocoll. 2019, 96, 343-353. [CrossRef]

30. NithyaBalaSundari, S.; Nivedita, V.; Chakravarthy, M.; Srisowmeya, G.; Usha, A.; Nandhini, D.G. Characterization of microbial polysaccharides and prebiotic enrichment of wheat bread with pullulan. LWT Food Sci. Technol. 2020, 109002. [CrossRef]

31. Shalini, R.; Abinaya, G.; Saranya, P.; Antony, U. Growth of selected probiotic bacterial strains with fructans from Nendran banana and garlic. LWT Food Sci. Technol. 2017, 83, 68-78. [CrossRef]

32. Macfarlane, G.; Macfarlane, S.; Gibson, G. Validation of a three-stage compound continuous culture system for investigating the effect of retention time on the ecology and metabolism of bacteria in the human colon. Microb. Ecol. 1998, 35, 180-187. [CrossRef]

33. Grimaldi, R.; Cela, D.; Swann, J.R.; Vulevic, J.; Gibson, G.R.; Tzortzis, G.; Costabile, A. In vitro fermentation of B-GOS: Impact on faecal bacterial populations and metabolic activity in autistic and non-autistic children. FEMS Microbiol. Ecol. 2017, 93. [CrossRef]

34. Astó, E.; Méndez, I.; Rodríguez-Prado, M.; Cuñé, J.; Espadaler, J.; Farran-Codina, A. Effect of the Degree of Polymerization of Fructans on Ex Vivo Fermented Human Gut Microbiome. Nutrients 2019, 11, 1293. [CrossRef] 
35. Herrera, P.; O'Bryan, C.; Crandall, P.; Ricke, S. Growth response of Salmonella enterica Typhimurium in co-culture with ruminal bacterium Streptococcus bovis is influenced by time of inoculation and carbohydrate substrate. Food Res. Int. 2012, 45, 1054-1057. [CrossRef]

36. Likotrafiti, E.; Valavani, P.; Argiriou, A.; Rhoades, J. In vitro evaluation of potential antimicrobial synbiotics using Lactobacillus kefiri isolated from kefir grains. Int. Dairy J. 2015, 45, 23-30. [CrossRef]

37. Valdés-Varela, L.; Hernández-Barranco, A.M.; Ruas-Madiedo, P.; Gueimonde, M. Effect of Bifidobacterium upon Clostridium difficile growth and toxicity when co-cultured in different prebiotic substrates. Front. Microbiol. 2016, 7, 738. [CrossRef]

38. Medina, D.A.; Pinto, F.; Ovalle, A.; Thomson, P.; Garrido, D. Prebiotics mediate microbial interactions in a consortium of the infant gut microbiome. Int. J. Mol. Sci. 2017, 18, 2095. [CrossRef]

39. Karetkin, B.A.; Guseva, E.V.; Evdokimova, S.A.; Mishchenko, A.S.; Khabibulina, N.V.; Grosheva, V.D.; Menshutina, N.V.; Panfilov, V.I. A quantitative model of Bacillus cereus ATCC 9634 growth inhibition by bifidobacteria for synbiotic effect evaluation. World J. Microbiol. Biotechnol. 2019, 35, 89. [CrossRef]

40. Oude Blenke, E.; Evers, M.J.; Baumann, V.; Winkler, J.; Storm, G.; Mastrobattista, E. Critical evaluation of quantification methods for oligonucleotides formulated in lipid nanoparticles. Int. J. Pharm. 2018, 548, 793-802. [CrossRef]

41. Gu, J.; Roberts, K. Probiotics and Prebiotics. In Adult Short Bowel Syndrome; Elsevier: Amsterdam, The Netherlands, 2019; pp. 67-80. [CrossRef]

42. Harris, S.; Powers, S.; Monteagudo-Mera, A.; Kosik, O.; Lovegrove, A.; Shewry, P.; Charalampopoulos, D. Determination of the prebiotic activity of wheat arabinogalactan peptide (AGP) using batch culture fermentation. Eur. J. Nutr. 2020, 59, 297-307. [CrossRef]

43. Thitiratsakul, B.; Anprung, P. Prebiotic activity score and bioactive compounds in longan (Dimocarpus longan Lour.): Influence of pectinase in enzyme-assisted extraction. J. Food Sci. Technol. 2014, 51, 1947-1955. [CrossRef]

44. Manisseri, C.; Gudipati, M. Prebiotic activity of purified xylobiose obtained from Ragi (Eleusine coracana, Indaf-15) Bran. Indian J. Microbiol. 2012, 52, 251-257. [CrossRef]

45. Barengolts, E. Gut microbiota, prebiotics, probiotics, and synbiotics in management of obesity and prediabetes: Review of randomized controlled trials. Endocr. Pract. 2016, 22, 1224-1234. [CrossRef]

46. Liu, Y.; He, J.; Xu, Q.; Zhang, C.; Chen, N.; Xie, X. Enhanced Adenosine Production by Bacillus subtilis at Condition with Comprehensively Controlled Dissolved Oxygen and pH During Fermentation. In Advances in Applied Biotechnology; Springer: Berlin, Germany, 2015; pp. 439-452.

47. Patel, A.K.; Singhania, R.R.; Pandey, A. Production, Purification, and Application of Microbial Enzymes. In Biotechnology of Microbial Enzymes; Elsevier: Amsterdam, The Netherlands, 2017; pp. 13-41. [CrossRef]

48. Connelly, S.; Shin, S.G.; Dillon, R.J.; Ijaz, U.Z.; Quince, C.; Sloan, W.T.; Collins, G. Bioreactor Scalability: Laboratory-Scale Bioreactor Design Influences Performance, Ecology, and Community Physiology in Expanded Granular Sludge Bed Bioreactors. Front. Microbiol. 2017, 8, 664. [CrossRef]

49. Coletta, A.; Molter, C.; Duqué, R.; Steenhoff, D.; Taminau, J.; de Schaetzen, V.; Lazar, C.; Meganck, S.; Nowé, A.; Bersini, H.; et al. InSilico DB: An online platform to collaboratively structure and export publicly available datasets from the Gene Expression Omnibus database. Genome Biol. 2011, 12, P33. [CrossRef]

50. Cannone, J.J.; Subramanian, S.; Schnare, M.N.; Collett, J.R.; D’Souza, L.M.; Du, Y.; Feng, B.; Lin, N.; Madabusi, L.V.; Müller, K.M.; et al. The comparative RNA web (CRW) site: An online database of comparative sequence and structure information for ribosomal, intron, and other RNAs. BMC Bioinform. $2002,3,2$.

51. Tsai, C.Y.; Huang, W.L. Design and performance modeling of an efficient remote collaboration system. Int. J. Grid Distrib. Comput. 2015, 8, 11-26. [CrossRef]

52. Ram, B.K.; Kumar, S.A.; Prathap, S.; Mahesh, B.; Sarma, B.M. Remote laboratories: For real time access to experiment setups with online session booking, utilizing a database and online interface with live streaming. In Online Engineering E Internet of Things; Springer: Berlin, Germany, 2018; pp. 190-204.

53. Tang, B.; Wang, Y.; Zhu, J.; Zhao, W. Web Resources for Model Organism Studies. Genom. Proteom. Bioinform. 2015, 13, 64-68. [CrossRef] [PubMed]

54. Singh, O.; Chang, N.W.; Dai, H.J.; Jonnagaddala, J. Translational Bioinformatics Databases. In Encyclopedia of Bioinformatics and Computational Biology; Elsevier: Amsterdam, The Netherlands, 2019; pp. 1058-1062. [CrossRef] 
55. Herce-Zelaya, J.; Porcel, C.; Bernabé-Moreno, J.; Tejeda-Lorente, L.; Herrera-Viedma, E. Web platform for learning distributed databases' queries processing. Procedia Comput. Sci. 2019, 162, 827-834. [CrossRef]

56. Kritikos, K.; Magoutis, K.; Papoutsakis, M.; Ioannidis, S. A survey on vulnerability assessment tools and databases for cloud-based web applications. Array 2019, 3, 100011. [CrossRef]

57. Vathy-Fogarassy, G.; Hugyák, T. Uniform data access platform for SQL and NoSQL database systems. Inf. Syst. 2017, 69, 93-105. [CrossRef]

58. Markert, K.N.; Pulla, S.T.; Lee, H.; Markert, A.M.; Anderson, E.R.; Okeowo, M.A.; Limaye, A.S. AltEx: An open source web application and toolkit for accessing and exploring altimetry datasets. Environ. Model. Softw. 2019, 117, 164-175. [CrossRef]

(C) 2020 by the authors. Licensee MDPI, Basel, Switzerland. This article is an open access article distributed under the terms and conditions of the Creative Commons Attribution (CC BY) license (http://creativecommons.org/licenses/by/4.0/). 